Web Site: https://jutq.utq.edu.iq/index.php/main

Email: journal@jutq.utq.edu.iq

\title{
Assessment of the effect of video information on patient's anxiety undergoing cardiac catheterization in An Nasiriyah \\ city
}

https://doi.org/10.32792/utq/utj/vol12/1/11

\section{Ied Ali Omar \\ Qasim Ali Khazaal}

\section{Abstract}

The researcher applies descriptive study to assessment of the effect of video information on patient's anxiety undergoing cardiac catheterization in An Nasiriyah city. Study aims: is to assess effect of video information on patient's anxiety undergoing cardiac catheterization. The setting of study: The study was performed in An Nasiriyah city; between (9/February to 3/March / 2015), in An Nasiriyah heart center - in Medical Wards. The study sample: A non-probability (purposive) sample of (100) patients. The study population consisted of a sample of adults from both genders whose ages were 30 years and more, and was newly diagnosed as having CAD (coronary artery disease) and they admitted to hospital in order to confirm the diagnosis by coronary angiography in the cardiac catheterization unit of An Nasiriyah heart center. Data collection: The data, which were collected in the hospital for the period from 9 of February to 3 of March / 2015, include in two major parts was constructed for the purpose of the study:- 1-socio-demographic characteristic, which includes 5 variables(items) (age, gender, occupational status, level of education, marital status) 2- the 


\section{University of Thi-Qar Journal Vol.12 No.1 Mar 2017 \\ Web Site: https://jutq.utq.edu.iq/index.php/main \\ Email: journal@jutq.utq.edu.iq}

questionnaire related to signs \& symptoms of anxiety, which includes of (5) items \& (26) sub-items: Nervous system included (lack of concentration, headache, insomnia, muscle spasm, nervous, dizziness, frequent sweaty, dry mouth, fear ,Trembling, Un happiness, Crying easily, Numbness, Sensitivity to nose), Cardiovascular system included (palpitation, fatigue \& restlessness), Digestive system included (anorexia, difficulty in swallowing, dysphagia, nausea, \& diarrhea), Respiratory system included (shortness of breathing, increase of respiration (over breathing) ), Urinary system included (Nocturia, Increase the number of times urination. Data analysis: the data was analyzed through the use of statistical approaches. They are descriptive statistical analysis (frequencies, percentage, SD, Range of scores, mean of scores and relative sufficiency. Results: The result of the study showed the samples that have low or absent pre-test anxiety level were (39 (39\%)). The moderate level were (52 (52\%)) and the high level were (9 (9\%), While the result shows the of samples that have low or absent post-test anxiety level were $(79(79 \%))$. The moderate level were (21 (21\%), Recommendation: Based on the above results, this study recommends conducting An education program should be designed to increase information of the patients about anxiety associated with coronary angiography. Also Prepare educational video (animation video about the procedure) for the patients before one-hour pre-operation to decrease anxiety, as well as the establishing specialized educational center to provide information and educate patient before coronary angiography procedure. 


\section{University of Thi-Qar Journal Vol.12 No.1 Mar 2017 \\ Web Site: https://jutq.utq.edu.iq/index.php/main \\ Email: journal@jutq.utq.edu.iq}

Keywords: Assessment, anxiety, cardiac catheterization, video information

\section{الخلاصة}

أجريت در اسة وصفية لتقييم تأثثر معلومات الفيديو على قلق المرضى الخاضعين للقسطرة القليية

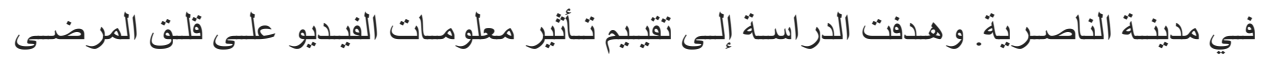

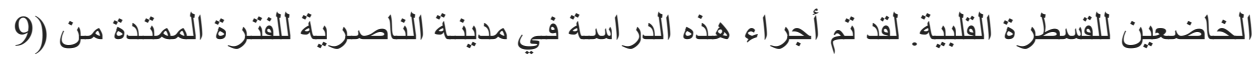
فبر اير إلى 3 مارس 2015) وذللك في مركز الناصرية للقلب في الأجنحة ألطبيـة. عينـة الدراسـة شملت (100) من المرضى اختيروا من مركز الناصرية للقلب. اختيرت عينة غرضيه (غير

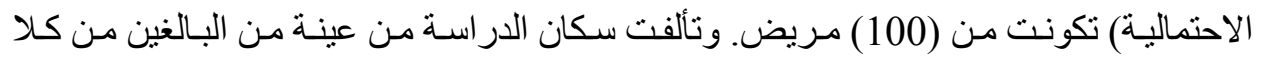

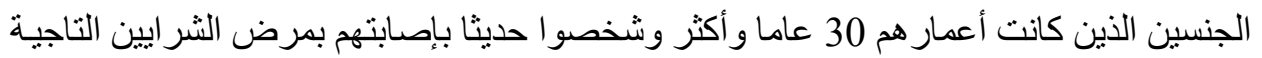

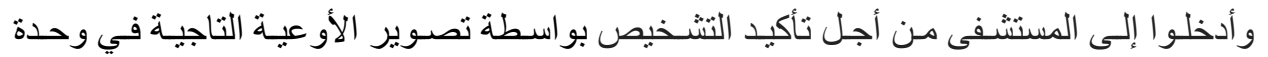
قسطرة القلب بمركز الناصرية للقلب. وتشمل البيانات التي تم جمعها في المستشفى للفترة من 9

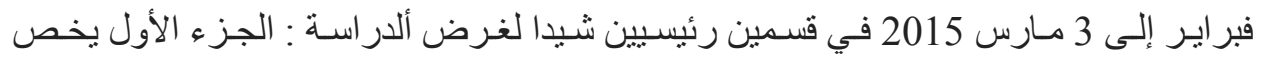
المعلومـات الاجتماعية و الديمغر افيـة والتي تضم 5 متغير ات (عناصر ) العمر, الجنس، و والحاللة المهنيـة، ومستوى التعليم، الحالـة الاجتماعيـة) إمـا الجزء الثناني فيثـمل الاستبيان الذي يتعلق بعلامـات و أعـر اض القلق، و الذذي يتضـمن مـن (5) متغيـرات ( بنـود) و(26) مـن المتغيـرات

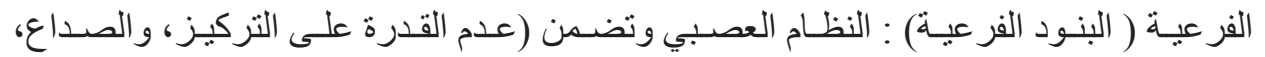
و الأرق، وتثنج العضـلات، و العصبية، و الدو ار، وكثرة العرق، وجفاف الفم، و الخوف)، نظـام

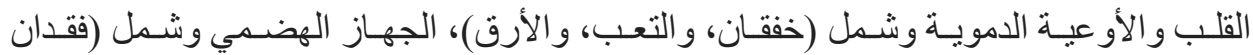
الثهية، صعوبة في البلح، اضطر اب في المعدة، و الغثيان، والإسهال)، الجهاز التنفسي وشمل

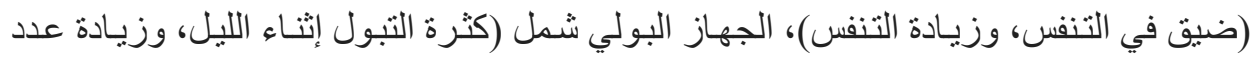
مر ات التبول. تحليل البيانات: تم تحليل البيانات من خلال استخدام أساليب إحصـائية. هي التحليل الإحصـائي الوصفي (التكر ارات و النسب المئويـة، الانحر اف المعياري، مدى الأعداد الكبيرةِ،

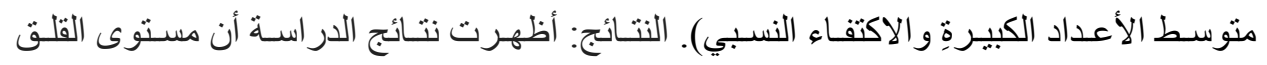




\section{University of Thi-Qar Journal Vol.12 No.1 Mar 2017 \\ Web Site: https://jutq.utq.edu.iq/index.php/main \\ Email: journal@jutq.utq.edu.iq}

للعينات التي لديها مستوى القلق منخفض أو غائب ما قبل إجر اء الاختبار هي (39 (39 ٪)).

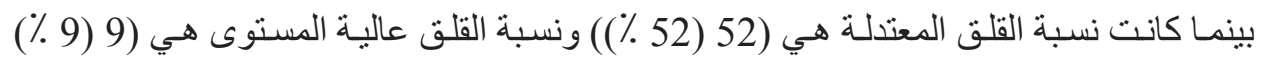

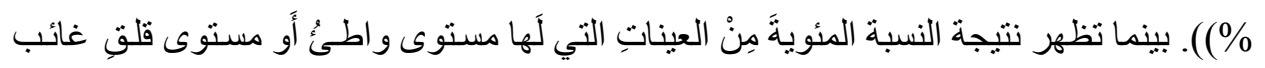
ما بعد الاختبار هي (79 (79 \%)). نسبة القلق معتدلة المستوى كانتُ (21 (21\%) (21).التوصيات:

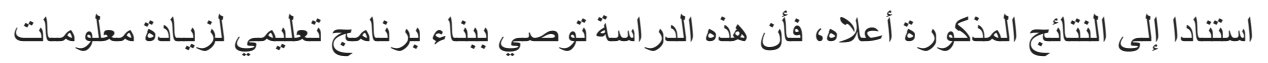

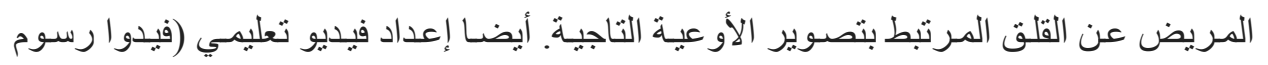

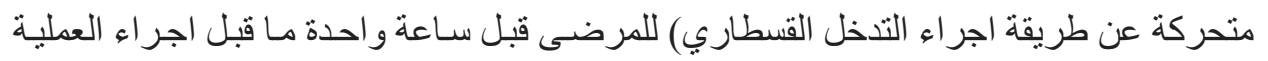

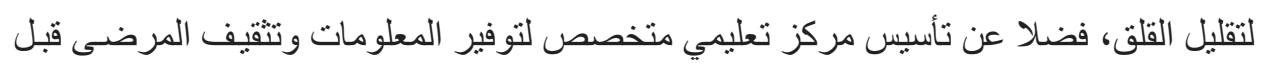
إجر اء تصوير الأوعية التاجية.

\section{Introduction}

The heart disease has become a major killer of mankind. With the vast changes in the lifestyle of people, cardiac problems are increasing day by day in our country, also the cardiovascular disease are becoming a leading cause of morbidity and mortality among coronary vascular disease. The coronary artery disease has become the most important cause of pre matured death and disability in the population in some countries on death among three men around the age of 55 years is due to $\operatorname{CAD}(1,2)$.

Coronary heart disease is the single leading cause of death in the United States. Cardiovascular diseases are responsible for the lives of $41.4 \%$ of more than 2.3 million Americans who die each year. Nearly 59 million Americans have some form of cardiovascular disease, ranging from congenital heart defects to high blood pressure and atherosclerosis (3). 


\section{University of Thi-Qar Journal Vol.12 No.1 Mar 2017 \\ Web Site: https://jutq.utq.edu.iq/index.php/main \\ Email: journal@jutq.utq.edu.iq}

With the development of hemodynamic studies and interventional and diagnostic techniques, the mortality rate of coronary heart diseases decreased significantly (4).

Presently, heart catheterization is the most used hemodynamic interventional and diagnostic technique worldwide and accounts for approximately six thousand procedures per one million inhabitants, per year, in Western counties. The complication and restenosis rates are low $(5,6)$.

Cardiac catheterization is the insertion of a catheter up to the aorta and left ventricle by puncturing the brachial or femoral artery. Images of the coronary arteries are shown by injecting contrast through the catheter. This procedure is used for diagnostic assessment to confirm or determine the extent and severity of the cardiopathy (6).

Although being the test of choice to diagnose and treat coronary disease, it still presents potential risks, such as arrhythmias, embolism, neurologic alterations, and vasovagal changes, in addition to ischemic, allergic and vascular complications (7).

Cardiac catheterization is generally an elective procedure in which a symptomatic patient with heart disease follows a protocol that requires admission to hospital $(8,9)$. 


\section{University of Thi-Qar Journal Vol.12 No.1 Mar 2017 \\ Web Site: https://jutq.utq.edu.iq/index.php/main \\ Email: journal@jutq.utq.edu.iq}

Waiting for the procedure can be a major source of stress and anxiety. These feelings are directly related to the invasive nature of the procedure and to uncertainties related to diagnosis (10).

In daily practice it is observed that patients do not understand clearly information given by the healthcare team due to stress and anxiety. In this context of waiting and anxiety, relatives are also stressed and share feelings and uncertainties with the patients, thus turning the situation more complex for the nursing team, since these experiences are mainly witnessed by nurses (10).

In the daily routine, nurses find it difficult to deal with patients' and relatives' anxiety in the pre-catheterization period. This may be justified or worsened by the lack of specific nursing standards related to family support (10).

In face of this situation, nurses should get the best pieces of information available to deliver a better care, thus diminishing the stressing factors to reduce patients' and relatives' anxiety (10).

\section{MATERIALS AND METHODOLOGY}

\section{Administration Arrangement}

Written official permission has been obtained from college of nursing, training \& employ development department of Thi-qar \& An Nasiriya heart center in An Nasiriya city.

\section{Setting of the Study}

The study was conducted in the medical cardiac wards in tow times, pre-test after the patients admitted to the hospital and post-test, before the 


\section{University of Thi-Qar Journal Vol.12 No.1 Mar 2017 \\ Web Site: https://jutq.utq.edu.iq/index.php/main \\ Email: journal@jutq.utq.edu.iq}

patient's confirm diagnosis CAD by cardiac catheterization in the An Nasiriya heart center, in An Nasiriya city, Thi-qar, Iraq.

\section{Design of the Study}

A descriptive study was carried out through the present investigation in order to achieve the objects of the present study. Data collection started from 9 of February to 3 of March / 2015. 


\section{University of Thi-Qar Journal Vol.12 No.1 Mar 2017 \\ Web Site: https://jutq.utq.edu.iq/index.php/main \\ Email: journal@jutq.utq.edu.iq}

\section{The Sample of the Study}

A non-probability (purposive) sample of (100) patients was selected. All the patients who had primary diagnosed CAD and they had a medical records and admitted to the cardiac wards for An Nasiriyah Heart Center hospital.

\section{Tool of the study:}

For the purpose of the present study, a questionnaire was designed $\&$ constructed by the researcher to measure the variable. Such as construction was employed through the review of literature \& related studies. The questionnaire comprised of (2) parts, related to the following:

\section{Part I: Socio- Demographic Data:}

It consists of (5) items, related to the Socio-demographic characteristics of these patients which include age, gender, occupational status, level of education, marital status.

\section{Part II: Signs \& Symptoms of Anxiety Level:}

It consists of (5) items \& (26) sub-items:

Nervous system included (lack of concentration, headache, insomnia, muscle spasm, nervous, dizziness, frequent sweaty, dry mouth, fear ,Trembling, Un happiness, Crying easily, Numbness, Sensitivity to nose), Cardiovascular system included (palpitation, fatigue \& restlessness), Digestive system included (anorexia, difficulty in swallowing, dysphagia, nausea, \& diarrhea), Respiratory system included (shortness of breathing, increase of respiration (over breathing) ), Urinary system included (Nocturia, Increase the number of times urination). 


\section{University of Thi-Qar Journal Vol.12 No.1 Mar 2017 \\ Web Site: https://jutq.utq.edu.iq/index.php/main \\ Email: journal@jutq.utq.edu.iq}

- This part was measured through anxiety level. pre-test and post-test.

- All these items were rated and scored by five level types option scale as absent (0), mild (1), moderate (2), severe (3), very severe (4). The high score of anxiety level obtained, it means higher modification by patients.

Five rating scale were used as follows:

Collection number of scale $\div$ no of scale $=$ cut of point

$(0+1+2+3+4)=10 \quad$ so $10 \div 5=2$ cut of point

$$
\begin{aligned}
& =\frac{\text { cut of point }}{\text { no.of scale }} \times 100 \\
& =\frac{2}{5} \times 100=
\end{aligned}
$$

So the interval had been ranged, between (40 -100) that, represented the rate of the lifestyle modification.

$=\frac{100-40}{5}=12$

Suggestion was made for classifying the early stated interval for anxiety level into main categories as follows:

$40+12=52$

$(40-52)$ is little level

(52.1-64.1) is mild level

$(64.2-76.2)$ is moderate level

$(76.3-88.3)$ is severe level

$(88.4-100)$ is very severe level

In addition, less than 40 its mean there is no anxiety

\section{Statistical Analysis}




\section{University of Thi-Qar Journal Vol.12 No.1 Mar 2017}

Web Site: https://jutq.utq.edu.iq/index.php/main

Email: journal@jutq.utq.edu.iq

The data analyzed through the application of statistical procedures and using the package of SPSS version (20).

The following statistical procedures are used in this study:

\section{Descriptive Statistical Procedures}

This approach was performed through the determination of:

Frequency (f) , Percentage (\%), $\%=\Sigma f / \mathrm{n}^{\times} \mathbf{1 0 0}$

\section{Inferential Statistical Procedures}

Reliability (r) $\quad r=\frac{\Sigma \mathrm{xy}-n\left(x^{-}\right)\left(y^{-}\right)}{\sqrt{\left[\Sigma \mathrm{x}^{2}-\mathrm{n}\left(\mathrm{x}^{-}\right)^{2}\right]\left[\Sigma \mathrm{y}^{2}-\mathrm{n}\left(\mathrm{y}^{-}\right)^{2}\right]}}$

\section{RESULTS}

Figure.1: Percentage Distribution of the Study Population by Diagnosis

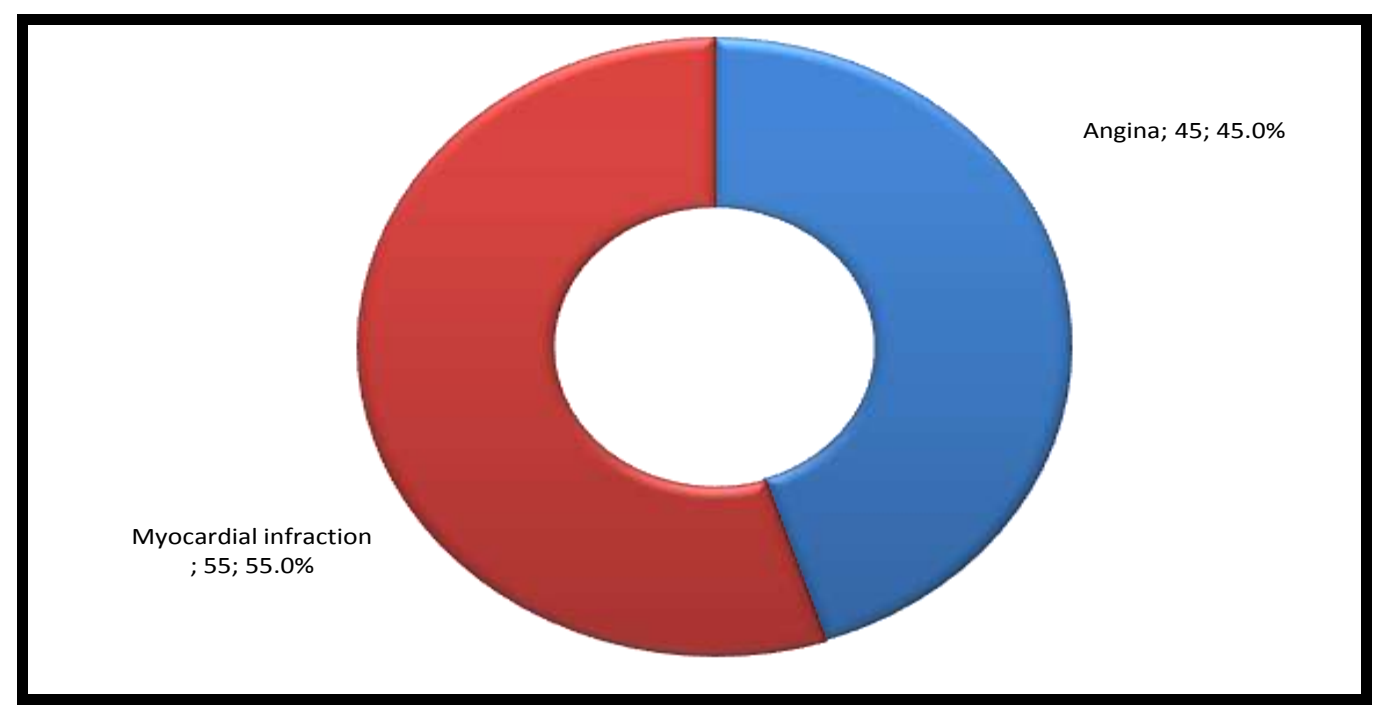




\section{University of Thi-Qar Journal Vol.12 No.1 Mar 2017}

Web Site: https://jutq.utq.edu.iq/index.php/main

Email: journal@jutq.utq.edu.iq

$\mathrm{n}=$ number of samples, $\mathrm{F}=$ frequency, $\%=$ percentage

This figure shows that $(55.55 \%)$ of the study sample have a myocardial infarction, while (45.45\%) of patients have angina.

Table (1) Distribution of Patients according to Socio - Demographic

Characteristic no $=100$

\begin{tabular}{|c|c|c|c|}
\hline Variable & & no & $\%$ \\
\hline \multirow{5}{*}{ Age } & $30-39$ & 7 & 7.0 \\
\hline & $40--49$ & 13 & 13.0 \\
\hline & $50--59$ & 30 & 30.0 \\
\hline & $60--69$ & 33 & 33.0 \\
\hline & $70--79$ & 17 & 17.0 \\
\hline \multirow{2}{*}{ Sex } & Male & 85 & 85.0 \\
\hline & Female & 15 & 15.0 \\
\hline \multirow{7}{*}{ Level of Education } & Illiterate & 23 & 23.0 \\
\hline & Read \& write & 21 & 21.0 \\
\hline & Primary school graduate & 27 & 27.0 \\
\hline & Secondary school graduate & 7 & 7.0 \\
\hline & Intermediate school graduate & 14 & 14.0 \\
\hline & High Institute graduate & 7 & 7.0 \\
\hline & University \& Higher education & 1 & 1.0 \\
\hline \multirow{4}{*}{ Marital status } & Single & 2 & 2.0 \\
\hline & Married & 84 & 84.0 \\
\hline & Divorced & 1 & 1.0 \\
\hline & Widowed & 13 & 13.0 \\
\hline \multirow{5}{*}{ Occupation } & Unemployed & 30 & 30.0 \\
\hline & Government employee & 23 & 23.0 \\
\hline & Self-employee & 10 & 10.0 \\
\hline & House wife & 18 & 18.0 \\
\hline & Retired & 19 & 19.0 \\
\hline
\end{tabular}

$\mathrm{n}=$ number of samples, $\mathrm{F}=$ frequency,$\%=$ percentage 


\section{University of Thi-Qar Journal Vol.12 No.1 Mar 2017}

\section{Web Site: https://jutq.utq.edu.iq/index.php/main}

\section{Email: journal@jutq.utq.edu.iq}

This table shows that the high percentage $(33 \%)$ of patients ages from (60 to 69 years old). Most of them $(85.0 \%)$ were male. The education level represents $(27 \%)$ of CAD were primary school graduate. Most of them (84.0\%) were married, and (30.0\%) were unemployed.

\section{Table (2) Assessment of pre-test anxiety level value of CAD Patients} according to Mean of Scores and Relative Sufficiency

\begin{tabular}{|c|c|c|c|c|c|c|c|c|}
\hline \multirow[t]{2}{*}{ Pretest Items } & Absent & mild & Moderate & Severe & $\begin{array}{c}\text { Very } \\
\text { sever } \\
\text { e } \\
\end{array}$ & \multirow[t]{2}{*}{ MS } & \multirow[t]{2}{*}{$\mathbf{R S}$} & \multirow[t]{2}{*}{ Score } \\
\hline & no(\%) & no $(\%)$ & no(\%) & no(\%) & no(\%) & & & \\
\hline $\begin{array}{l}\text { Lack of } \\
\text { concentratio } \\
\text { n }\end{array}$ & $44(44.0)$ & $32(32.0)$ & $21(21.0)$ & $3(3.0)$ & $0(0.0)$ & 0.83 & 16.6 & $\begin{array}{l}\text { no anxiety } \\
\text { effect }\end{array}$ \\
\hline Headache & $42(42.0)$ & $17(17.0)$ & $26(26.0)$ & $13(13.0)$ & $2(2.0)$ & 1.16 & 23.2 & $\begin{array}{l}\text { no anxiety } \\
\text { effect }\end{array}$ \\
\hline Insomnia & 30 & 21 & 23 & 16 & 10 & 1.55 & 31 & $\begin{array}{l}\text { no anxiety } \\
\text { effect }\end{array}$ \\
\hline $\begin{array}{l}\text { Muscle } \\
\text { spasms }\end{array}$ & 27 & 22 & 28 & 14 & 9 & 1.56 & 31.2 & $\begin{array}{l}\text { no anxiety } \\
\text { effect }\end{array}$ \\
\hline Nervousness & 20 & 23 & 22 & 31 & 4 & 1.58 & 31.6 & $\begin{array}{l}\text { no anxiety } \\
\text { effect }\end{array}$ \\
\hline Trembling & 46 & 24 & 24 & 5 & 1 & 0.91 & 18.2 & $\begin{array}{l}\text { no anxiety } \\
\text { effect }\end{array}$ \\
\hline Dizziness & 42 & 24 & 18 & 13 & 3 & 1.11 & 22.2 & $\begin{array}{l}\text { no anxiety } \\
\text { effect }\end{array}$ \\
\hline Numbness & 37 & 21 & 24 & 18 & 0 & 1.23 & 24.6 & $\begin{array}{l}\text { no anxiety } \\
\text { effect }\end{array}$ \\
\hline $\begin{array}{l}\text { Un } \\
\text { happiness } \\
\end{array}$ & 25 & 34 & 22 & 14 & 5 & 1.40 & 28 & $\begin{array}{l}\text { no anxiety } \\
\text { effect }\end{array}$ \\
\hline Sweating & $37(37.0)$ & $20(20.0)$ & $23(23.0)$ & 17 & $3(3.0)$ & 1.29 & 25.8 & $\begin{array}{l}\text { no anxiety } \\
\text { effect }\end{array}$ \\
\hline Dry mouth & 34 & 12 & 31 & 17 & 6 & 1.49 & 29.8 & $\begin{array}{l}\text { no anxiety } \\
\text { effect }\end{array}$ \\
\hline $\begin{array}{l}\text { Crying } \\
\text { easily }\end{array}$ & 9 & 8 & 26 & 40 & 17 & 2.48 & 49.6 & little \\
\hline Fear & 9 & 29 & 24 & 25 & 13 & 2.04 & 40.8 & little \\
\hline Palpitation & 36 & 25 & 28 & 10 & 1 & 1.15 & 23 & $\begin{array}{l}\text { no anxiety } \\
\text { effect }\end{array}$ \\
\hline Fatigue & 33 & 22 & 25 & 18 & 2 & 1.34 & 26.8 & $\begin{array}{l}\text { no anxiety } \\
\text { effect }\end{array}$ \\
\hline Restlessness & 20 & 26 & 28 & 22 & 4 & 1.64 & 32.8 & no anxiety \\
\hline
\end{tabular}




\section{University of Thi-Qar Journal Vol.12 No.1 Mar 2017 \\ Web Site: https://jutq.utq.edu.iq/index.php/main \\ Email: journal@jutq.utq.edu.iq}

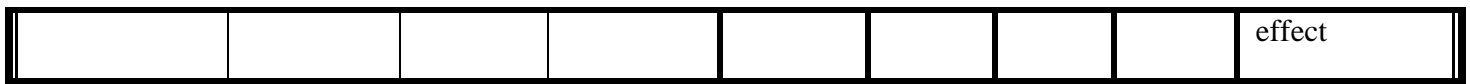

Cut off point $=2, \mathrm{No}=$ number, $\%=$ percentage, $\mathrm{MS}=$ mean of score, $\mathrm{RS}=$ relative sufficiency, no effect of anxiety level modification $=$ less than $(40)$, little $=(40-52)$, mild level $=(52.1-$

62.1 $)$, moderate level $=(64.2-76.2)$, severe level $=(76.3-88.3)$, very sever $=(88.4$ to 100$)$.

Table (2) represents pre-test anxiety level, it shows that the crying easily and fear, have very little relative sufficiency, and all the anxiety level value were record no anxiety effect.

\section{Table (3) Assessment of pre-test anxiety level value of CAD Patients according to Mean of Scores and Relative Sufficiency}

\begin{tabular}{|c|c|c|c|c|c|c|c|c|}
\hline Pretest Items & $\begin{array}{c}\text { Absent } \\
\text { no }(\%)\end{array}$ & $\begin{array}{l}\text { mild } \\
\text { no(\%) }\end{array}$ & $\begin{array}{r}\text { Moderate } \\
\text { no }(\%)\end{array}$ & $\begin{array}{c}\text { Severe } \\
\text { no }(\%)\end{array}$ & $\begin{array}{c}\begin{array}{c}\text { Very } \\
\text { sever } \\
\text { e }\end{array} \\
\text { no }(\%)\end{array}$ & $\begin{array}{c}\mathbf{M} \\
\mathbf{S}\end{array}$ & $\mathbf{R S}$ & Score \\
\hline $\begin{array}{l}\text { Loss of } \\
\text { appetite }\end{array}$ & 14 & 14 & 34 & 27 & 11 & 2.07 & 41.4 & ] little \\
\hline $\begin{array}{l}\text { Difficult in } \\
\text { swallowing }\end{array}$ & 63 & 13 & 18 & $\overline{5}$ & 1 & 0.68 & 13.6 & $\begin{array}{c}\text { no anxiety } \\
\text { effect }\end{array}$ \\
\hline $\begin{array}{l}\text { Epigastric } \\
\text { discomfort }\end{array}$ & 35 & 31 & 24 & 8 & 2 & 1.11 & 22.2 & $\begin{array}{c}\text { no anxiety } \\
\text { effect }\end{array}$ \\
\hline nausea & 57 & 24 & 14 & 4 & 1 & 0.68 & 13.6 & $\begin{array}{c}\text { no anxiety } \\
\text { effect }\end{array}$ \\
\hline Diarrhea & 66 & 19 & 10 & 5 & $\overline{0}$ & 0.54 & 10.8 & $\begin{array}{c}\text { no anxiety } \\
\text { effect }\end{array}$ \\
\hline $\begin{array}{l}\text { Shortness of } \\
\text { breathing }\end{array}$ & 38 & 29 & 19 & 13 & 1 & 1.10 & 22 & $\begin{array}{c}\text { no anxiety } \\
\text { effect }\end{array}$ \\
\hline $\begin{array}{l}\text { Over } \\
\text { breathing }\end{array}$ & 37 & 19 & 28 & 15 & 1 & 1.24 & 24.8 & $\begin{array}{c}\text { no anxiety } \\
\text { effect }\end{array}$ \\
\hline $\begin{array}{l}\text { Sensitivity to } \\
\text { nose }\end{array}$ & 68 & 9 & 15 & 8 & 0 & 0.63 & 12.6 & $\begin{array}{c}\text { no anxiety } \\
\text { effect }\end{array}$ \\
\hline Nocturnal & 22 & 37 & 23 & 15 & 3 & 1.40 & 28 & $\begin{array}{c}\text { no anxiety } \\
\text { effect }\end{array}$ \\
\hline
\end{tabular}


University of Thi-Qar Journal Vol.12 No.1 Mar 2017

Web Site: https://jutq.utq.edu.iq/index.php/main

Email: journal@jutq.utq.edu.iq

\begin{tabular}{|l|c|c|c|c|c|c|c|c||}
\hline $\begin{array}{l}\text { Frequency of } \\
\text { urination }\end{array}$ & 19 & 34 & 22 & 19 & 6 & 1.59 & 31.8 & $\begin{array}{c}\text { no anxiety } \\
\text { effect }\end{array}$ \\
\hline Total & $\mathbf{1 0 0 \%}$ \\
\hline
\end{tabular}

Cut off point $=2, \mathrm{No}=$ number, $\%=$ percentage, $\mathrm{MS}=$ mean of score, $\mathrm{RS}=$ relative sufficiency, no effect of anxiety level modification $=$ less than $(40)$, little $=(40-52)$, mild level $=(52.1-$ 62.1 $)$, moderate level $=(64.2-76.2)$, severe level $=(76.3-88.3)$, very sever $=(88.4$ to 100$)$.

Table (3) represents anxiety level pretest, it shows that the loss of appetite has very little relative sufficiency, and all the anxiety level value were record no anxiety effect.

\section{Table (4) Assessment of post-test anxiety level value of CAD Patients according to Mean of Scores and Relative Sufficiency}

\begin{tabular}{|c|c|c|c|c|c|c|c|c|}
\hline \multirow{2}{*}{ Posttest Items } & Absent & mild & Moderate & Severe & $\begin{array}{c}\text { Very } \\
\text { severe }\end{array}$ & \multirow{2}{*}{ MS } & \multirow{2}{*}{$\mathbf{R S}$} & \multirow{2}{*}{ Score } \\
\hline & no(\%) & $\begin{array}{r}\text { no(\% } \\
)\end{array}$ & no(\%) & no(\%) & no(\%) & & & \\
\hline $\begin{array}{l}\text { Lack of } \\
\text { consternation }\end{array}$ & 72 & 22 & 6 & 0 & 0 & 0.43 & 6.8 & $\begin{array}{c}\text { no anxiety } \\
\text { effect }\end{array}$ \\
\hline Headache & 59 & 28 & 7 & 6 & 0 & 0.60 & 12 & $\begin{array}{c}\text { no anxiety } \\
\text { effect }\end{array}$ \\
\hline Insomnia & 64 & 15 & 10 & 9 & 2 & 0.70 & 14 & $\begin{array}{c}\text { no anxiety } \\
\text { effect }\end{array}$ \\
\hline $\begin{array}{l}\text { Muscle } \\
\text { tension }\end{array}$ & 67 & 15 & 9 & 9 & 0 & 0.60 & 12 & $\begin{array}{c}\text { no anxiety } \\
\text { effect }\end{array}$ \\
\hline Nervousness & 65 & 15 & 8 & 11 & 1 & 0.68 & 13.4 & $\begin{array}{c}\text { no anxiety } \\
\text { effect }\end{array}$ \\
\hline Trembling & 74 & 20 & 5 & 1 & 0 & 0.33 & 7.6 & $\begin{array}{c}\text { no anxiety } \\
\text { effect }\end{array}$ \\
\hline Dizziness & 65 & 19 & 10 & 6 & 0 & 0.57 & 11.4 & $\begin{array}{c}\text { no anxiety } \\
\text { effect }\end{array}$ \\
\hline Numbness & 68 & 16 & 11 & 4 & 1 & 0.54 & 10.8 & $\begin{array}{c}\text { no anxiety } \\
\text { effect }\end{array}$ \\
\hline
\end{tabular}


University of Thi-Qar Journal Vol.12 No.1 Mar 2017

Web Site: https://jutq.utq.edu.iq/index.php/main

Email: journal@jutq.utq.edu.iq

\begin{tabular}{|l|c|c|c|c|c|c|c|c||}
\hline Un happiness & 49 & 19 & 16 & 13 & 3 & 1.02 & 20.4 & $\begin{array}{c}\text { no anxiety } \\
\text { effect }\end{array}$ \\
\hline Sweating & 76 & 13 & 6 & 4 & 1 & 0.41 & 8.5 & $\begin{array}{c}\text { no anxiety } \\
\text { effect }\end{array}$ \\
\hline Dry mouth & 45 & 33 & 11 & 11 & 0 & 0.88 & 13.5 & $\begin{array}{c}\text { no anxiety } \\
\text { effect }\end{array}$ \\
\hline Crying easily & 64 & 10 & 13 & 11 & 2 & 0.77 & 15.5 & $\begin{array}{c}\text { no anxiety } \\
\text { effect }\end{array}$ \\
\hline Fear & 61 & 13 & 16 & 9 & 1 & 0.76 & 15.2 & $\begin{array}{c}\text { no anxiety } \\
\text { effect }\end{array}$ \\
\hline Palpitation & 70 & 18 & 8 & 4 & 0 & 0.46 & 9.2 & $\begin{array}{c}\text { no anxiety } \\
\text { effect }\end{array}$ \\
\hline Fatigue & 64 & 13 & 17 & 6 & 0 & 0.65 & 13 & $\begin{array}{c}\text { no anxiety } \\
\text { effect }\end{array}$ \\
\hline Restlessness & 64 & 21 & 17 & 13 & 3 & 1.06 & 21.2 & $\begin{array}{c}\text { no anxiety } \\
\text { effect }\end{array}$ \\
\hline Total & $100(\%)$ & & & & & & & \\
\hline
\end{tabular}

Cut off point $=2, \mathrm{No}=$ number, $\%=$ percentage, $\mathrm{MS}=$ mean of score, $\mathrm{RS}=$ relative sufficiency, No effect of anxiety level modification $=$ less than $(40)$, little $=(40-52)$, mild level $=(52.1-$

62.1 $)$, moderate level $=(64.2-76.2)$, severe level $=(76.3-88.3)$, very sever $=(88.4$ to 100$)$.

The findings of this table indicated that the evaluation of relative sufficiency was on effected for post-test anxiety level value.

Table (5) Assessment of post-test anxiety level value of CAD Patients according to Mean of Scores and Relative Sufficiency

\begin{tabular}{|c|c|c|c|c|c|c|c|c|}
\hline \multirow{2}{*}{ Posttest Items } & $\begin{array}{c}\text { Absen } \\
t\end{array}$ & Little & Moderate & Severe & $\begin{array}{c}\text { Very } \\
\text { severe }\end{array}$ & \multirow{2}{*}{ MS } & \multirow{2}{*}{$\mathbf{R S}$} & \multirow{2}{*}{ Score } \\
\hline & no(\%) & no(\%) & no(\%) & no(\%) & no(\%) & & & \\
\hline Loss of appetite & 63 & 20 & 9 & 7 & 1 & 0.63 & 12.6 & $\begin{array}{r}\text { no anxiety } \\
\text { effect }\end{array}$ \\
\hline Difficult in swallowing & 78 & 20 & 2 & 0 & 0 & 0.24 & 4.8 & $\begin{array}{r}\text { no anxiety } \\
\text { effect }\end{array}$ \\
\hline Epigastria discomfort & 68 & 15 & 15 & 2 & 0 & 0.51 & 10.5 & $\begin{array}{r}\text { no anxiety } \\
\text { effect }\end{array}$ \\
\hline
\end{tabular}




\section{University of Thi-Qar Journal Vol.12 No.1 Mar 2017 \\ Web Site: https://jutq.utq.edu.iq/index.php/main \\ Email: journal@jutq.utq.edu.iq}

\begin{tabular}{|l|c|c|c|c|c|c|c|r||}
\hline Nausea & 56 & 29 & 12 & 3 & 0 & 0.62 & 12.4 & $\begin{array}{r}\text { no anxiety } \\
\text { effect }\end{array}$ \\
\hline Diarrhea & 86 & 11 & 3 & 0 & 0 & 0.17 & 3.5 & $\begin{array}{r}\text { no anxiety } \\
\text { effect }\end{array}$ \\
\hline Shortness of breathing & 65 & 27 & 6 & 2 & 0 & 0.45 & 9 & $\begin{array}{r}\text { no anxiety } \\
\text { effect }\end{array}$ \\
\hline Over breathing & 70 & 23 & 3 & 4 & 0 & 0.41 & 6.4 & $\begin{array}{r}\text { no anxiety } \\
\text { effect }\end{array}$ \\
\hline Sensitivity to nose & 83 & 14 & 2 & 1 & 0 & 0.21 & 5.8 & $\begin{array}{r}\text { no anxiety } \\
\text { effect }\end{array}$ \\
\hline Nocturnal & 54 & 33 & 10 & 2 & 1 & 0.63 & 12.5 & $\begin{array}{r}\text { no anxiety } \\
\text { effect }\end{array}$ \\
\hline Frequency of urination & 52 & 27 & 17 & 4 & 0 & 0.73 & 14.6 & $\begin{array}{r}\text { no anxiety } \\
\text { effect }\end{array}$ \\
\hline Total & & & & & & & & \\
\hline
\end{tabular}

Cut off point $=2$, No= number, $\%=$ percentage, $M S=$ mean of score, $R S=$ relative sufficiency, No effect of anxiety level modification $=$ less than $(40)$, little $=(40-52)$, mild level $=(52.1-$

62.1 $)$, moderate level $=(64.2-76.2)$, severe level $=(76.3-88.3)$, very sever $=(88.4$ to 100$)$.

The findings of this table indicated that the evaluation of relative sufficiency was on effected for posttest anxiety level value.

Figure .2: Pie Chart for Distribution of Patients according to pre-test anxiety levels Score 


\section{University of Thi-Qar Journal Vol.12 No.1 Mar 2017}

Web Site: https://jutq.utq.edu.iq/index.php/main

Email: journal@jutq.utq.edu.iq

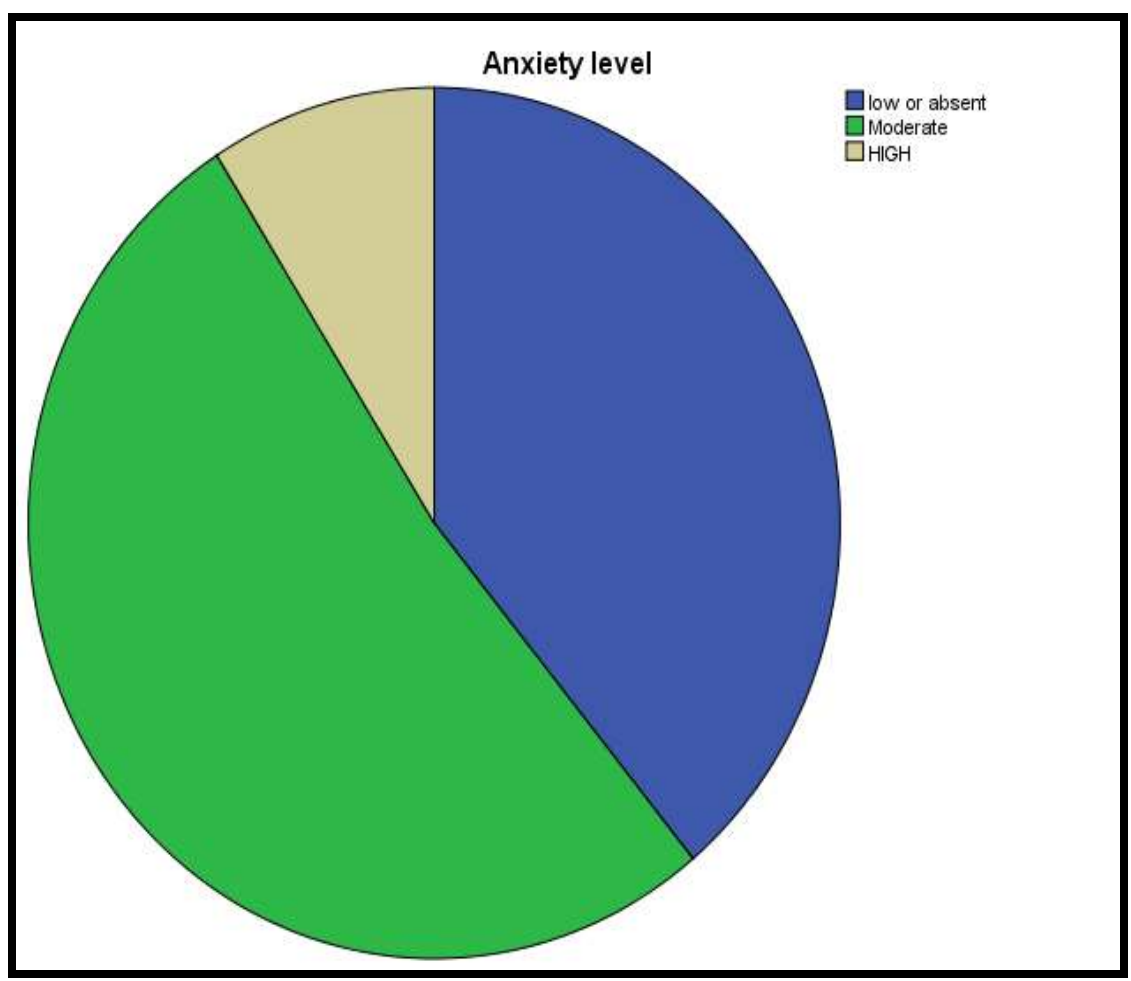

Figure (2) shows the percentage of samples that have low or absent

\begin{tabular}{|l|c|c|c|c|}
\hline Level of anxiety & Frequency & Percent \% & Valid Percent & Cumulative Percent \\
\hline low or Absent & 39 & 39.0 & 39.0 & 39.0 \\
\hline Moderate & 52 & 52.0 & 52.0 & 91.0 \\
\hline High & 9 & 9.0 & 9.0 & 100.0 \\
\hline Total & 100 & 100.0 & 100.0 & \\
\hline
\end{tabular}

pre-test anxiety level were (39 (39\%)). The moderate level was (52

$(52 \%))$ and the high level were (9 (9\%).

Figure .3: Pie Chart for Distribution of Patients according to posttest anxiety levels Score 


\section{University of Thi-Qar Journal Vol.12 No.1 Mar 2017}

Web Site: https://jutq.utq.edu.iq/index.php/main

Email: journal@jutq.utq.edu.iq

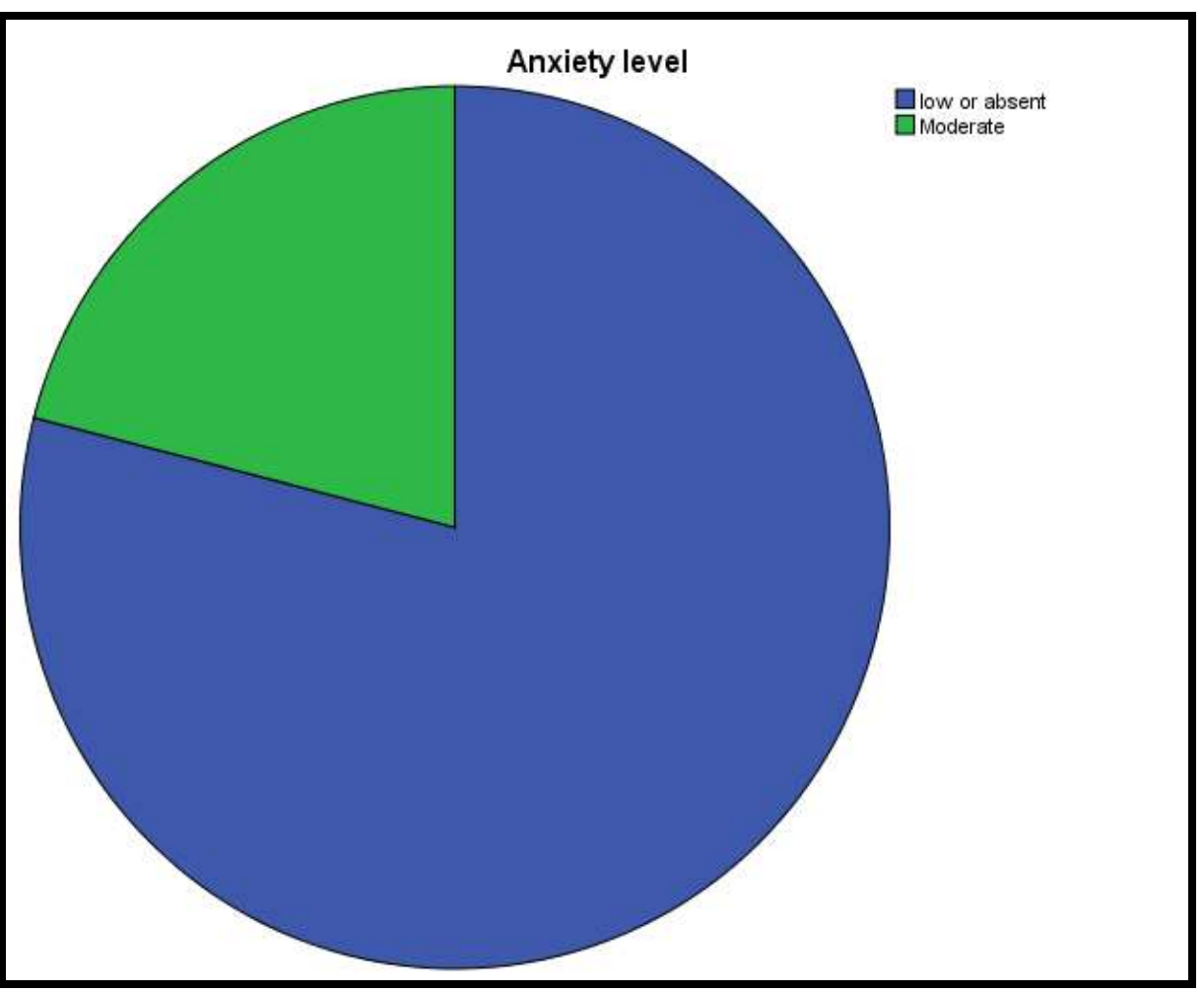

\begin{tabular}{|l|c|c|c|c|}
\hline Level of anxiety & Frequency & $\begin{array}{c}\text { Percent } \\
\%\end{array}$ & Valid Percent & Cumulative Percent \\
\hline low or absent & 79 & 79.0 & 79.0 & 79.0 \\
\hline Moderate & 21 & 21.0 & 21.0 & 100.0 \\
\hline Total & 100 & 100.0 & 100.0 & \\
\hline
\end{tabular}

Figure (3) shows the percentage of samples that have low or absent post-test anxiety level were $(79(79 \%))$. The moderate level was (21 $(21 \%))$.

\section{DISCUSSION}

Undergoing coronary angiography is very stressful experience for many patients. This confirms the usefulness and effectiveness of video information prior to coronary angiography. 


\section{University of Thi-Qar Journal Vol.12 No.1 Mar 2017 \\ Web Site: https://jutq.utq.edu.iq/index.php/main \\ Email: journal@jutq.utq.edu.iq}

\section{Part II: Result of Assessment of pre-test anxiety level value of CAD Patients according to Mean of Scores and Relative Sufficiency}

Table 2): analysis was conducted 5 items \& 26 sub-items of the questionnaire that evaluated of pre-test anxiety, the anxiety score contains from 5 levels as (absent, mild, moderate. sever, very sever) a result of this study had shown that majority (52\%) of the study moderate level. The results of this study is similar to results of the study conducted in Iran, April 2009, which was 6.38 _ 3.70 (13).

The patient's anxiety related to little information about the disease and procedure. The level of education, play main role for anxiety experience because most of them have low levels of education.

\section{Part III: result of Assessment of post-test anxiety level value of CAD Patients according to Mean of Scores and Relative Sufficiency}

Table 3): analysis was conducted 5 items and 26 sub items of the questionnaire that evaluated of posttest anxiety, the anxiety score contains from 5 levels as (absent, little, moderate, sever, very sever) are result of this study had shown that majority (79\%) of the study low or absent level. The results of this study is similar to results of the study conducted in Iran, April 2009, which was $3.30_{-}^{+} 2.67$ (13).

Another study in Iran for 100 patients show, the seventy-eight (60.9\%) males and fifty (39.1\%) females participated in the study. There was a statistically significant reduction in the Anxiety, stress and depression levels of experimental group after video information $(\mathrm{P}=.000)$. There was 


\section{University of Thi-Qar Journal Vol.12 No.1 Mar 2017 \\ Web Site: https://jutq.utq.edu.iq/index.php/main \\ Email: journal@jutq.utq.edu.iq}

a statistically significant correlation between sex with anxiety $(\mathrm{P}=.000)$ and stress $(\mathrm{P}=.04)(13)$. The use of patients' education by informative video is a useful method for decreasing psychological parameters of patients undergoing coronary angiography procedure, the video informatics education its more effective than verbal education because there is a Differences levels of education and patient's knowledge regarded to procedure and disease

\section{CONCLUSIONS:}

In accordance with the results of this study, the researcher can conclude the following:

1. Because the patient doesn't know about the coronary angiography procedure that is lead to increase the anxiety for the most patients according to anxiety level score show the moderate level of anxiety is $52 \%$.

2. The current study shows effected video information for these patients undergoing for coronary angiography lead to decrease the level of anxiety for them (moderate anxiety is $21 \%$ ).

\section{Recommendations}

According to the results of the study, the researcher puts the following recommendations:

1. An education program should be designed to increase information of the patient about anxiety associated with coronary angiography.

2. Prepare educational video for the patients before one hour pre operation to decrease anxiety. 


\section{University of Thi-Qar Journal Vol.12 No.1 Mar 2017 \\ Web Site: https://jutq.utq.edu.iq/index.php/main \\ Email: journal@jutq.utq.edu.iq}

3. Establishing specialized educational center to provide information and educate patient before coronary angiography procedure.

4. Training and development programs for nursing staff working in An Nasiriya Heart Center about coronary artery disease (causes, types of coronary artery disease, risk factors, prevention methods and how to deal with patients at risk of a heart attack), As well as the establishment of nursing courses to learn how to do rehabilitation for all patients to survive when they want to do cardiac catheterization, to prevent anxiety and depression and possible complications of the heart attacks. 


\section{University of Thi-Qar Journal Vol.12 No.1 Mar 2017 \\ Web Site: https://jutq.utq.edu.iq/index.php/main \\ Email: journal@jutq.utq.edu.iq}

\section{References}

1. Nancy S: A reference manual for nurses on coronary artery nursing, 3rd ed. Delhi, Kumar Publishing House, 2003. P: 3.

2. Nikhil P.: A Study to Assess the Effectiveness of Self Instructional Module On Knowledge Regarding Role of Antioxidant Diet Among the Patients with Coronary Artery Disease in Selected Hospital, Bangalore. 4th Block, Jayanagar, Bangalore - 41, Karnataka, 2009.

3. American Heart Association. Heart disease and stroke statistics-2008 update. Retrieved February 8, 2008, from www.americanheart.org.

4. Dotter CT. Transluminally-placed coilspring endarterial tube grafts. Long-term patency in canine popliteal artery. Invest Radiol. 1969;4(5):329-32.

5. Brito FS Jr, Ariê S, Caixeta AM, Soares PR, Obregon A, Perin MA, et al. Abordagem terapêutica da reestenose após implante de stent coronário. Rev Bras Cardiol Invas. 1997;5(1):37-46.

6. Lima LR, Pereira SV, Chianca TC. Diagnósticos de enfermagem em pacientes pós-cateterismo cardíaco: contribuição de Orem. Rev Bras Enferm. 2006;59(3):285-90.

7. Guérios EE, Bueno RR, Andrade PM, Nercolini DC, Pacheco AL. Stents. Uma revisão da literatura. Arq Bras Cardiol. 1998;71(1):77-87.

8. American Heart Association. (2010). What Your Cholesterol Levels.

9. Mean.Http://www.americanheart.org/presenter.jhtml? identifier=183 (Accessed January )15, 2010. 


\section{University of Thi-Qar Journal Vol.12 No.1 Mar 2017 \\ Web Site: https://jutq.utq.edu.iq/index.php/main \\ Email: journal@jutq.utq.edu.iq}

10.Grazziano ES, Bianchi ER. Nível de ansiedade de clientes submetidos a cineangiocoronariografia e seus acompanhantes. Rev Lat-Am Enf. 2004;12(2):168-74.

11. Sobhi N. El-Yazji.: Coronary Artery Disease Nutritional Assessment Among Adult Population in Gaza Strip, Hospital Based Case-Control Study. Al-Azhar University of Gaza Deanship of Postgraduate Studies and Research Affairs. March, 2011, A thesis.

12. AHA Conference Proceedings: Summary of the Scientific: Conference on Dietary Fatty Acids and Cardiovascular Health,Circulation, 2006, vol. 103, p.p1034-1039 . 